ON THE RECORD

"This is the National

Hurricane Center

signing off for

2005...finally."

A forecaster at the hurricane centre in Miami, Florida, breathes a sigh of relief that Tropical Storm Zeta has finally dissipated, more than a month after the hurricane season ended.

\section{“Like the Loch Ness monster, this can bring some good for our country."}

A tourist of ficial in Malaysia hopes for aflood of visitors now that Bigfoot has apparently been seen there.

Source National Hurricane Center, Associated Press

\section{SCORECARD}

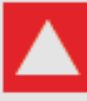

Asthma

For once, your mobile phone could be good for your health. Some London-based networks are offering a textmessaging service that alerts as thma sufferers to bad-air days.

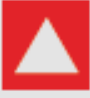

Being called $\mathbf{L} \mathbf{i}$ A survey of 300 million Chinese people has revealed that the country's most popular surname is $\mathrm{Li}$, a name held by $7.4 \%$ of the population. Second and third ranked are Wang and Zhang, held by $7.2 \%$ and $6.8 \%$ of people, respectively.

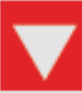

Booze in space

Arumour that Russia will bring alcohol aboard the International Space Station is quashed by teetotal NASA.

\section{NUMBER CRUNCH}

A report by Germany's Centre for University Development has led newspaper Die Zeit to suggest that German universities could maybe learn a trick or two from their US counterparts when it comes to raising additional funds.

$\$ 540$ million was raised by Harvard University in 2003 - the most raised by any US university that year.

$\$ 16$ million was raised by the University of Mannheim - the most raised in Germary in 2003.

$50 \%$ of Germanuniversities do not do any fundraising at all.

\title{
DNA tests put death penalty under fire
}

\section{WASHINGTON DC}

US campaigners against capital punishment are hoping that modern DNA tests in old cases will undermine public confidence in the death penalty.

In the next few weeks, genetic testing of an old sample could show that Roger Keith Coleman - executed in 1992 for rape and murder - was not guilty. The tests are being conducted at Canada's Centre of Forensic Sciences in Toronto, and were requested by the state of Virginia's governor, Mark Warner. If Coleman is exonerated, it will be the first time that genetic evidence is used to prove that the US death penalty has killed an innocent person.

Coleman was convicted in Virginia for the 1981 murder of his sister-in-law. The sample being tested was gathered in 1990 as part of an unsuccessful attempt to clear his name. In ordering the recent tests, Warner - a Democrat widely expected to run for president in 2008 - called Coleman's case "an extraordinarily unique circumstance, where technology has advanced significantly and can be applied in the case of someone who consistently maintained his innocence until execution.

Only once before in the United States has DNA been tested in a case where the prisoner had already been executed. The tests, performed in 2000, were inconclusive about the guilt of the Georgia man, Ellis Felker, who had been executed four years earlier.

But modern DNA tests have successfully exonerated some Virginia prisoners. Between 2002 and 2004, three people were cleared after tests were done on old biological samples, saved by a methodical employee in the era before such techniques were available. As a result, Warner asked for tests on a random $10 \%$ of all the samples that had been saved. Out of thousands of cases,

"Retesting DNA samples is the only morally acceptable course." there were 29 in which current DNA tests could have shown guilt or innocence. Two of the 29 were shown to be innocent and their convictions overturned.

Warner has now announced that the rest of the samples will also be tested, calling this " the only morally acceptable course. Ellen Qualls, the governor's communications director, says
IMAGE

UNAVAILABLE FOR COPYRIGHT REASONS

that a rough extrapolation from the test results suggests there may be 20 or 30 exonerations from around 300 pertinent cases - an error rate that some would argue is unacceptable for a state that allows capital punishment.

The US public has long been divided over the death penalty. Each state decides whether to administer it or not: 38 states allow people to be sentenced to death, and Illinois has suspended executions while it examines the issue. Proof that innocents have died would certainly strengthen arguments against the penalty.

The issue of wrongful convictions does not apply just to cases that pre-date DNA testing. A growing scandal in Texas serves as a reminder that genetic tests are only as reliable as those carrying them out. On 4 January, a damning report was published on the Houston Police Department's crime laboratory. The DNA unit of the Texas lab was closed in 2002, after a series of exposés by local television news station KHOU. Now, an independent investigation, which has looked at 1,100 cases so far, charges the lab with problems including contamination of samples, misrepresentation of 


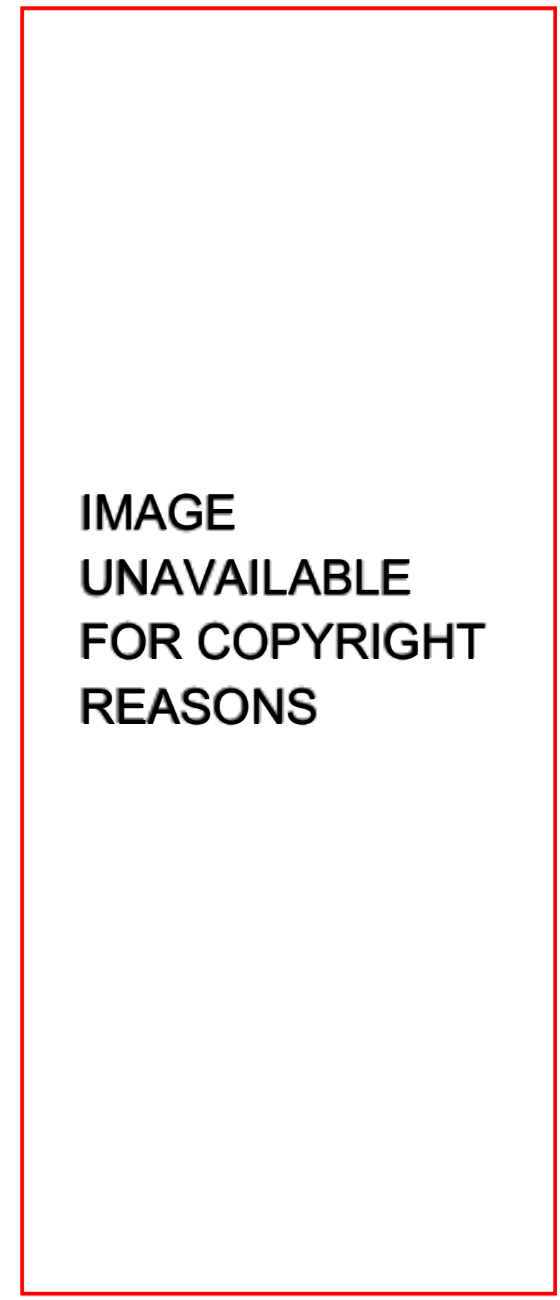

Innocents at risk: the United States is in a furore over questionable DNA evidence.

statistics in court and failure to use controls. In two cases, one of which put a man on death row, a dear absence of the suspect's genetic markers in a sample was called "inconclusive" and not reported.

Investigators blamed lack of funding and inept management, among other factors. ${ }^{\alpha}$ The complete lack of outside scrutiny of the crime lab's operations, procedures, and reporting of results allowed serious deficiencies...to become so egregious that analysts in the lab simply had no perspective on how bad their practices were, ${ }^{n}$ the report reads. DNA analysed at the lab is being retested, and at least one person has been freed.

Nearly $95 \%$ of US police crime laboratories are accredited by a board that maintains national standards. Ralph Keaton, head of the accreditation project, says that Houston's experience is the exception rather than the rule. "From the beginning," he says, "DNA evidence has been carefully scrutinized because it is so powerful."

Emma Marris

\section{Bird lovers keep sharp eye on owls}

Should wild animals be reintroduced into areas where they have become extinct? In recent years, the issue has split European conservationists and farmers, who disagree over the future of speciessuch as wolves. Now the unexpected arrival of a tiny population of owls in Britain has divided even ad wocates of conservation.

The breeding pair of eagle owls (Bubo bubo) first attracted attention last autumn, when they featured in a television documentary. Many ornithologists believe that the birds, which have a wingspan of two metres, haven't lived in Britain since the lastice age, 10,000 years ago. The owls are fearsome hunters, happy to dine on mammals - sometimes as large as small deer - or on other birds of prey.

The Royal Society for the Protection of Birds is calling on the British government to monitor the new arrivals, resident in Yorkshire in northern England, in case the population grows. The society is wor ried that the owls might start to kill significant numbers of endangered species, such as black grouse and hen harriers.

But some researchers argue that eagle owls should be protected as native birds. John Stewart, a palaeontologist at University College London, says fossil evidence suggests that the owls survived previous ice ages. He argues that remains from the past 10,000 yearss hould be taken as evidence that the owls existed in the wild ornithologists had previously assumed that the remains came from tame eagle owls that had been imported for hunting. "If youlook at the

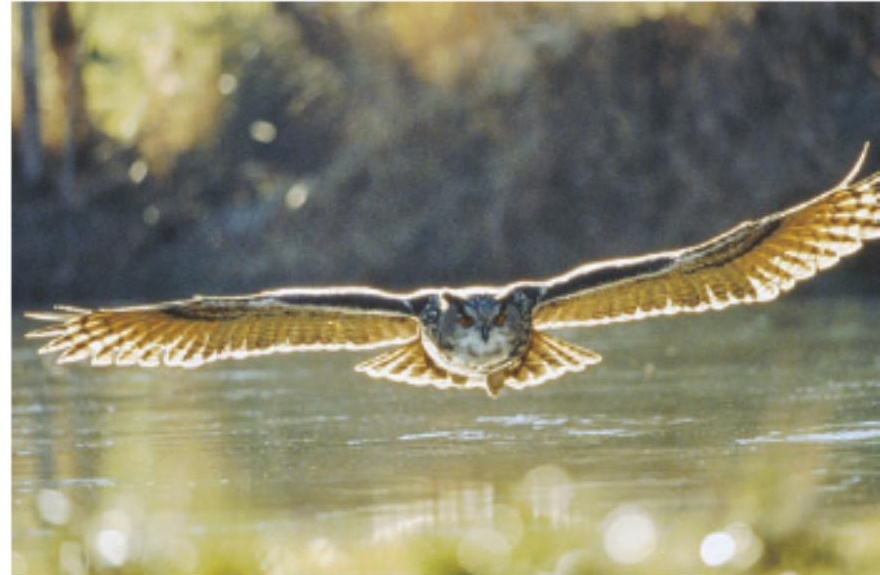

Soar point: should the eagle owl be allowed to repopulate Britain?

owls' distribution around

Europe, it is like that of other animals such as wolves and beavers thathave been pushed out of northwest Europe," adds Stewart. "It's churlish to suggest that they don't belong here."

If he is right, eagle owls could be added to the British List, the register of birds recorded in recent times in Britain and Ireland. This would give them the right to be protected, and perhaps even actively reintroduced. But Tim Melling, secretary of the records committee at the British Ornithologists' Union, which compiles the list, says he is not convinced by Stewart's points.

Melling says he and colleagues have reviewed every published British bird book and found no 'It's churlish to evidence for an suggest that established the owls don't population of eagle ow $\mathrm{k}$. He belong here." points out that the birds have been

popular pets for hundreds of years and that reports of wild eagle owls often note that the animals are unusually tame.

A similar debate over belonging was ignited last year by carbon dating of bones of the Eurasian lynx (Lynx lynx) from caves in Yorkshire. The lynx was thought to have died out in Britain several thousand years ago, when climate change turned much of its foresthabitat intoboggy peatlands. But the bones were just 1,500 years old, suggesting thatrecenthuman activity was responsible for the animals' demise.

The result was a boost for conservationists wanting to bring the lynx back to Britain, including David Hetherington, wholed the carbon-dating study at the University of Aberdeen. Hesuggests that forestry projects and deer in the Scottish Highlands would provide suitable habitat and prey.

Butwhatever the fossil evidence, any reintroduction needs local backing, cautions Toby Aykroyd, vice-chairman of the Wilderness Foundation, a charity based in Chelmsford, Essex. Farmers in France have protestedagainst the return of wolves, which prey on livestock. And beavers, which have been successfully reintroduced in mary European countries, have proved controversial in Britain: farmersfear they will be not be allowed to remove the animals from their land. Jim Giles

\section{$\frac{\vec{a}}{\frac{a}{3}}$}

